\title{
Véralvadásgátló kezelés elektrofiziológiai beavatkozások során
}

\author{
Som Zoltán
}

Gottsegen György Országos Kardiológiai Intézet, Budapest

Levelezési cím: Dr. Som Zoltán, 1096 Budapest Haller u. 29., E-mail: soma7454@gmail.com

\begin{abstract}
A véralvadásgátló kezelést igénylő betegek száma folyamatosan emelkedik. A non-valvuláris pitvarfibrilláló betegek antikoaguláns kezelése az elmúlt években alapvetően változott meg az új típusú véralvadásgátló szerek megjelenésével. Mindeközben az elektrofiziológiai beavatkozások száma is fokozatosan emelkedik, az elvégzendő beavatkozások egyre komplexebbek és az idősödő populáció miatt az ilyen jellegű beavatkozásokra kerülő betegek egyre nagyobb arányban részesülnek vérlvadásgátló vagy trombocitaaggregáció-gátló kezelésben. Rendkívül fontos az antikoaguláns kezelés periprocedurális alkalmazásának helyes megválasztása, hiszen mind a vérzéses, mind a trombotikus szövődmények súlyosak, akár életveszélyesek lehetnek.
\end{abstract}

Kulcsszavak: periprocedurális véralvadásgátlás, abláció, pacemaker/ICD-beültetés

\section{Anticoagulation strategies during electrophysiology procedures}

The number of patientes taking oral anticoagulation therapy is continously growing. With the appearance of the new oral anticoagulants, the tretament strategy of the patientes with non-valvular atrial fibrillation changed fundamentally. During the past years the number and the complexity of the electrophsiology procedures is gradually growing. Due to the aging population, more and more patientes preparing to electrophysiology procedure are taking oral antocoagulation therapy. Choosing the optimal strategy of the periprocedural aticoagulation is of unique importance, due to the potential life threatening thrombotic or haemorrhagic complications of these procedures.

Keywords: periprocedural anticoagulation, ablation, pacemaker/ICD implantation

\section{Bevezetés}

Az elektrofiziológiai beavatkozások rendkívül elterjedtek, mind Európában, mind hazánkban évről évre egyre több ilyen jellegú procedúrát végzünk $(1,2)$. Idetartoznak a szívritmust szabályzó vagy monitorozó eszközök (pacemakerek, beültethető defibrillátorok - ICD-k), reszinkronizációs pacemakerek vagy ICD-k, illetve loop-recorderek) beültetése kapcsán végzett mútétek, valamint a különböző ritmuszavarok oki kezeléseként végzett katéterablációk. Részletes ajánlások állnak rendelkezésre arra vonatkozólag, hogy melyik beavatkozást mely pácienseknél és hogyan alkalmazzunk (3, $4,5)$. Mindegyik beavatkozás invazív procedúra, és bár alapvetően biztonságosak és hatékonyak, mégis nem elhanyagolható szövődményrátával kell számolnunk az elvégzésük során. Ezen szövődmények között rendre találunk súlyos, életveszélyes, illetve potenciálisan akár halállal végződő szövődményeket is $(5,6,7)$. Különösen így van ez azon páciensek esetében, akik valamilyen okból kifolyólag véralvadásgátló, illetve trombocitaaggregáció-gátló kezelés alatt állnak, mivel a vérzési rizikó ilyen esetekben értelemszerűen sokkal magasabb. A katéterablációk - főként a pitvarfibrilláció abláció - során ráadásul a procedúráknak nemcsak vérzéses, hanem kifejezett trombotikus szövődményei is ismertek, amelyek elkerülése céljából nagy menynyiségü véralvadásgátló gyógyszert kell alkalmazni az amúgy magas vérzési rizikójú beavatkozás során. Így aztán az antitrombotikus kezelést igénylő betegek esetében minden egyes beavatkozás során külön értékelni kell a beteg trombózisrizikóját, a beteg vérzési rizikóját, 
valamint a tervezett procedúra vérzési, illetve trombotikus rizikóját. Külön értékelni szükséges minden beavatkozás elött az antitrombotikus kezelés indokoltságát, szükségességét.

Jelen dokumentum célja, hogy vezérfonalat adjunk azon klinikusok kezébe, akik elektrofiziológiai beavatkozásra készülő pácienst kezelnek, hogy miként alkalmazza az esetlegesen szükséges antikoaguláns/ antitrombocita kezelést a periprocedurális időszakban. Külön tárgyaljuk a PM/ICD/CRT-implantációk és külön a katéterablációk során alkalmazandó antitrombotikus kezelési stratégiákat.

A helyzetet nem egyszerüsíti, hogy az elmúlt években megjelentek, és széles körben elterjedtek az új típusú, vagy direkt antikoaguláns gyógyszerek (NOAC/DOAC), amelyek periprocedurális alkalmazásáról még csak limitált adatok állnak rendelkezésre.

A vezérfonal kialakításában a nemzetközi ajánlások vonatkozó fejezeteit, illetve a témával kapcsolatban a közelmúltban megjelent fontosabb közleményeket vettük alapul.

\section{Antikoaguláns kezelés katéterablációk során \\ Periprocedurális antikoaguláns kezelés pitvarfibrilláció abláció során}

A panaszos pitvarfibrilláló betegek ritmuskontroll célú kezelésében mára már elsőként választható kezelési lehetőség a kuratív abláció, amelynek alapja a pulmonalis vénaizoláció, amit szükség esetén - föként nem paroxizmális pitvarfibrilláció esetén - egyéb ablációkkal lehet kiegészíteni a ritmuszavar-mentesség arányának növelése céljából $(3,5)$. Ezen beavatkozás során - bármilyen energiaforrást választunk is - meglehetősen hosszú időn keresztül katétereket „tartunk” a bal pitvarban, illetve magával az ablációval kiterjedt endothel-sérüléssel járó endokardiális léziókat hozunk létre. Mind a katéterekkel történő intrakardiális manőverezés, mind az abláció során létrehozott léziók trombogének, nem beszélve a pitvarfibrillációval járó alapvetően emelkedett trombózisrizikóról. A tromboembóliás szövődmények (stroke, tranziens iszkémiás attak, perifériás embolizáció) mellett a beavatkozás - annak invazív jellegéből adódóan - nem elhanyagolható vérzési rizikóval is jár, amely a behatolási kapuk körüli komplikációk, vérömlenyek, álaneurizmák, arteriovenosus fistulák (a nagyerek szúrása miatt), kardiális perforáció, perikardiális vérzés, tamponád (transseptalis szúrás, katétermanipuláció, abláció miatt), tüdővérzés (tüdővéna-sérülés miatt), gasztrointesztinális vérzés (nyelöcsősérülés miatt) és intracranialis vérzés formájában jelentkezhetnek $(5,7)$. A beavatkozást tehát alapvetően egyaránt magas trombózisrizikójúnak és magas vérzési rizikójúnak kell tekinteni. Mind a tromboembóliás, mind a vérzéses szövődmények potenciálisan életveszélyesek, akár halálosak lehetnek, emiatt rendkívül körültekintő véralvadásgátló kezelés alkalmazása szükséges.
A jelenleg érvényben lévő, az Európai Kardiológus Társaság által 2016-ban kiadott ajánlás (3) és a 2017 tavaszán publikált HRS/EHRA/ECAS/APHRS/SOLAECE expert konszenzus dokumentum (5) alapján a páciens trombózisrizikójától függetlenül a periprocedurális trombózisrizikó csökkentése céljából a tervezett abláció előtt legalább 4 héten át és a beavatkozást követően legalább 8 héten át terápiás szintű orális véralvadásgátló kezelés szükséges. Azon betegeknél, akiknél a beavatkozás előtti, illetve utáni terápiás antikoaguláns kezelés nem megoldható, a pitvarfibrilláció-abláció ellenjavallt. A postprocedurális 8 . héten túl az antikoaguláns kezelés folytatása a páciens tromboembóliás rizikójától (CHAS-VASc score) függ, nem a beavatkozás sikerességétöl.

A beavatkozás alatt (a transzszeptális szúrás időpontjától kezdődően) frakcionáltan vagy folyamatosan adagolt Na-Heparin adásával kell az ACT-t 300-400 másodperc között tartani az ACT 15-30 percenkénti monitorozásával. A procedúra végén a heparinhatás felfüggesztése (parenteralis protamin adásával) javasolt a katéterek eltávolításának szövődménymentes biztosításához (5).

A K-vitamin-antagonistával történő véralvadásgátló kezelés esetén a procedúra napjára korábban a tartós véralvadásgátló kezelés felfüggesztése és könnyủ molekulasúlyú heparin (LMWH) vagy nem frakcionált heparin adása volt az általános gyakorlat. Az elmúlt években megjelent tanulmányok eredményei alapján azonban mára már az érvényben lévő ajánlás is a megszakítás nélküli, terápiás orális antikoaguláns hatásban (cél INR 2-3 között) végzett ablációt javasolja a trombotikus komplikációk hatékonyabb kivédése és egyidejüleg a vérzéses szövődmények csökkentése céljából a K-vitamin-antagonistával kezelt betegek esetében $(3,5,8)$. Nem ilyen egyszerủ a helyzet az új típusú, vagy direkt ható antikoaguláns gyógyszert szedő betegek esetében. Ezen gyógyszerek évek óta forgalomban vannak, és a páciensek és a kezelőorvosok körében egyre növekvő népszerüségnek örvendenek. Az új típusú véralvadásgátlók nagy randomizált vizsgálatok alapján egyértelműen hatékony és biztonságos alternatívái a K-vitamin-antgonistáknak nonvalvuláris pitvarfibrilláló betegek véralvadásgátló kezelése során $(9,10,11)$.

Az új típusú antikoagulánsok kereskedelmi forgalomban való megjelenését és elterjedését követően elindult a periprocedurális alkalmazásuk vizsgálata is. Több megfigyeléses vizsgálat áll rendelkezésre ezzel kapcsolatban, azonban randomizált, nagy esetszámú vizsgálat nem minden egyes szer esetében elérhető.

Hagyományosan ezen szerek szedését a felezési időtől és a betegek vese-, illetve májfunkciójától függően a beavatkozás előtt 24-36-48 órával felfüggesztették, és szükség szerint LMWH vagy nem frakcionált $\mathrm{Na}$-Heparin adása történt a procedúráig, illetve azt követően a gyógyszerek újraindításáig $(3,5)$.

Az első összehasonlító vizsgálatok során az új típusú antikoaguláns gyógyszerek adását a procedúra idejé- 


\section{MEGÚJULT CSOMAGOLÁS A NAGYOBB BETEGBIZTONSÁGÉRT}

\section{A SYNCUMAR MITE 1 MG TABLETTÁK KÜLSÖ összetévesztés lehetőségét. \\ A Syncumar Forte 2 mg tabletták csomagolása változatlan marad.} CSOMAGOLÁSA 2017. ÁPRILISTÓL MEGVÁLTOZIK, csökkentve ezzel az egyéb gyógyszerekkel való

A csomagolás módosulásáról és annak ütemezéséről a gyógyszertárakat tájékoztatjuk. Kérjük, hívja fel betege figyelmét a változásra! Válassza ezentúl is a precízen irányítható, költséghatékony terápiát acenokumarollal!

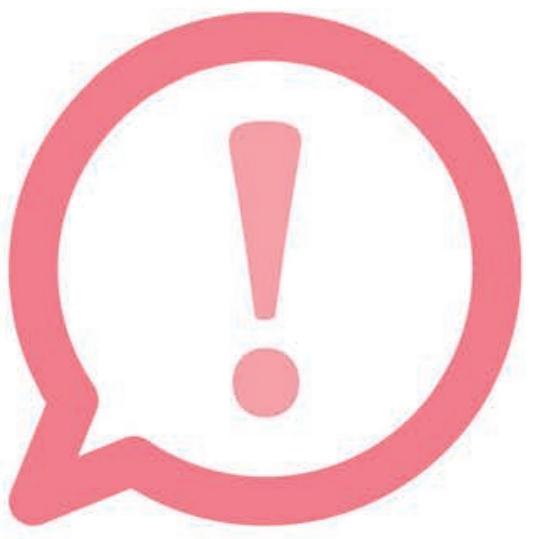

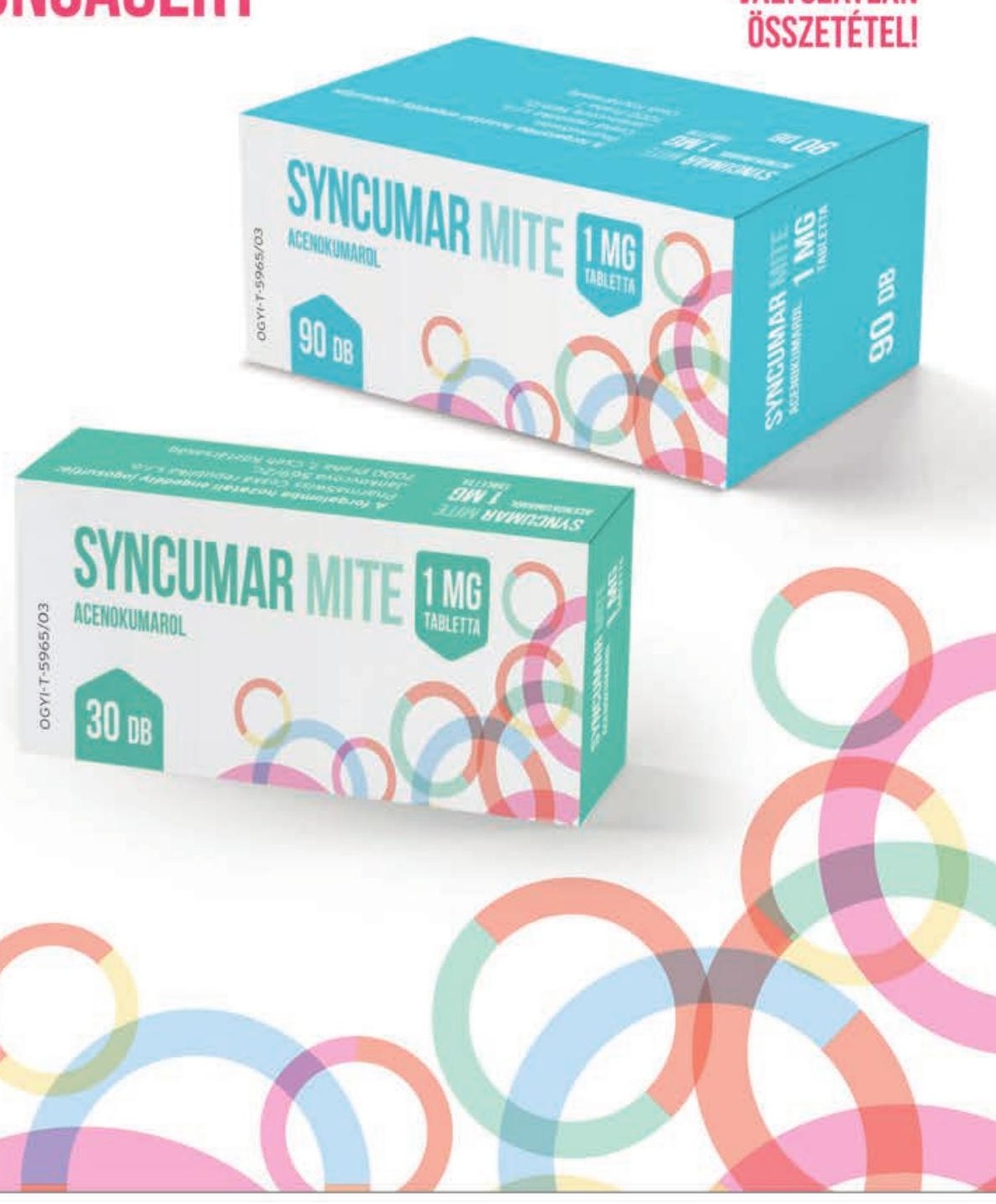

SYNCUMAR MITE 1 MG/FORTE 2 MG TABLETTA

Hatóanyag: acenokumarol. Terápiás javallatok: Vénás thromboembolia (VTE) (mélyvénás thrombosis és tüdõembólia) kezelésére és megelôzésére, felnötteknél. Szisztémás thromboembolia és ischaemiás stroke megelŏzése pitvarfibrilláció, mitralis stenosis és/vagy mitralis regurgitatio, dilatativ cardiomyopathia, biológiai és mechanikus mübillentyü-beültetés, kórelözményben szereplö myocardialis infarctus esetén. Akut myocardialis infarctus másodlagos megelözése. Adagolás és alkalmazás: A véralvadásgátlás hatásosságának monitorozása az INR rendszeres ellenörzése vel történik. A javasolt tartomány általában 2,0-3,0 között vann. A TTR-nek $60 \%$ felett kell lennie. A kezdó adag, ha azonnali alvadásgátló hatás létrehozása szükséges: 4 mg a kezelés 1. napján, a következö napokon 2-3 mg, amelyet az INR értékhez kell igazitani. Az INR-re gyakorolt hatás rendszerint 2-3 nap alatt kialakul. A kezelés 1.-3. naapján adandó kezdố adag bizonyos đozírozási algoritmusok - pl, az EU-PACT vizsoálat számitási módszere - felhasználásával, a klinikai adatok alapián elöre kiszámitott fenntartó dózissal is megadható. A kezdô adag, ha nem szüikséges azonnali alvadásgátló hatás, 2 mg körïli és az INR változásaihoz kell igazítani, A Syncumar fenntartó adagjai betegenként eltéróek, a napi átlagos fenntartó adag 2 mg körül van. A véralvadásǵt

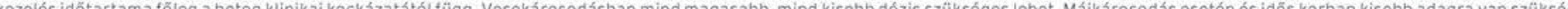

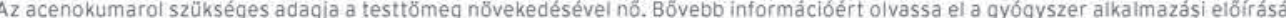
kokkal vagy bármely segédanyaggal szembeni tưlérzékenység. Terhesség. Akut vérzés sebekbôl, drénekbôli, sérülésekből, a hưgy-, légutakból, tápcsatornából. Súlyos politraumatizáció. Bármely más indikáció miatt kezdett, folyamatban lévő véralvadásgátló kezelés. Közelmúltban bekővetkezett intracranialis vérzés vagy olyan állapotok fennállása, melyek fokozzák az intracranialis vérzés kockázatát (pl. intracraniális aneurysma). Epiduralis anaesthesia, spinalis block a tervezett antikoaguláció elốtt 12 órán belül, epiduralis katéter egyidejố alkalmazása. Kezelés folyamatos ellenörzésének hiánya. Minden olyan körüilmény, amikor a haemorrhaglia becsült kockázata meghaladja a lehetséges klinikai előnyt. Bōvebb információért olvassa el a gyógyszer alkalmazási elöirását Különleges figyelmeztetések és óvintézkedések: Kontrollăit, mérsékelt véralvadási zavart idéz elö. A magas terápiás minōség és a magas TTR értẻk elérése érdekében elkerülhetetlen a folyamatos betegoktatás. Bövebb információért olvassa el a gyógyszer alkaimazási elốirását! Gyógyszerkölcsönhatások: Számos farmakokinetikai és farmakodinámiás kölcsönhatás lehetséges. Gyógyszer bevezetésekor/elhagyáskor köröltekintö klinikai/farmakológiaiértékelés szökséges. Egyik típusú orális alvadảsgátlóról egy másikra való áttérés nagymértékben megnöveli a vérzés

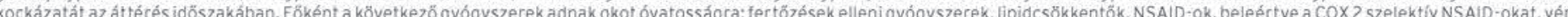

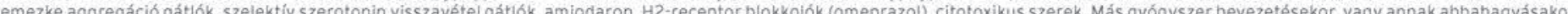

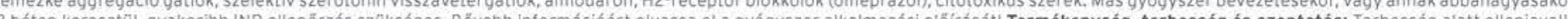
2 héten

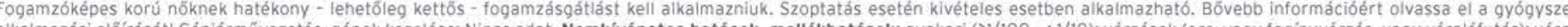
alkaimazási elörását! Gépjármüvezetés, gépek kezelése: Nincs adat. Nemkívánatos hatások, mellékhatások: gyakori ( $(21 / 100-<1 / 10)$ : vérzések (orr-vagy fogínyvérzés, vagy véraláfutás); véres vizelet, fekete vagy véres széklet, fokozott vagy elnyúitott menstruációs vérzés. Kórházi ellátást igénylổ jelentốs vêrzések is lehetnek. Anaemia. Ritka, de súlyos mellékhatás a Syncumar okozta börnekrớzis. Bővebb információért olvassa el a gyógyszer alkalmazási elö́rását! Tárolás: Legfeljebb $15^{\circ} \mathrm{C}-30^{\circ} \mathrm{C}$-on, a nedvességtöl való védelem érdekében az eredeti csomagolásban tárolandó. A FORGALOMBA HOZATALI ENGEDÉLY JOGOSULTJA: PharmaSwiss Ceská republika s.r.o., Jankovcova 1569/2c, 17000 Praha 7 Csehország. FORGALOMBA HOZATALI ENGEDÉLY SZÁMA: Syncumar mite $1 \mathrm{mg}$ tabletta (OGYI-T-5965/01-03) és Syncumar forte $2 \mathrm{mg}$ tabletta (OGYI-T-3147/01-02) Alkalmazási elöírás dátuma: 2016. március 03. ARAK: Syncumar Mite 1 mg tabletta 30x Közfinanszírozás alapjául elfogadott ár: $612 \mathrm{Ft}$. Normatív támogatás összege: $337 \mathrm{Ft}$. Térítési díj: $275 \mathrm{Ft}$, Közgyógy: igen; Syncumar Mite 1 mg tabletta $90 \times$ : Közfinanszírozás alapjául elfogadot: ár: $1705 \mathrm{Ft}$, Normativ támogatás összege: $938 \mathrm{Ft}$. Térítési dî: $767 \mathrm{Ft}$, Közoyógy: igen: Syncumar Forte 2 mg tabletta 30x: Kơzfinanszirozás alapiául elfogadott ár: $1158 \mathrm{Ft}$, Normativ támogatás összege: $637 \mathrm{Ft}$. Térítési dij: $521 \mathrm{Ft}$, Közgyógy: Igen: A fenti árak 2017 március 1-től érvényesek. Az árak időközi változásáról a www.neak.gov.hu oladalon tájékozódhat. Bövebb információért olvassa el a gyógyszer alkalmazási elöirását! További információk: Valeant Pharma Magyarország Kft., 1025 Budapest, Csatárka út 82-84., telefon: (+36) 1345 5900 
re leállították, így hasonlítva össze a megszakított vagy folyamatosan adagolt K-vitamin-antagonista hatásban történt beavatkozásokkal. Minden esetben a megszakítás időtartama alatt heparinnal történő áthidaló kezelést adtak. Az eredmények alapján sem vérzéses, sem trombotikus szövődmények tekintetében nem adódott különbség a K-vitamin-antagonisták, illetve az új típusú antikoaguláns szerek alkalmazása során, mutatva az új antikoaguláns gyógyszerek (dabigatran, rivaroxaban) periprocedurális alkalmazásának biztonságosságát $(12,13)$.

Ahogy a K-vitamin-antagonisák folyamatos periprocedurális adagolásának javaslata és a terápiás INR-szint mellett történő pitvarfibrilláció-abláció 2016-ra már evidenciává vált, az új típusú véralvadásgátlókkal is végeztek folyamatos periprocedurális adagolásra vonatkozó vizsgálatokat.

A megtartott rivaroxaban kezelés mellett végzett pitvarfibriláció-abláció a folyamatosan adagolt K-vitamin-antagonista mellett végzett ablációval összehasonlításban hasonlóan biztonságosnak bizonyult mind a vérzéses, mind a trombotikus szövődmények szempontjából. Ilyenkor a rivaroxabant a beavatkozás előtti estén, majd a beavatkozás estéjén a közvetlen vérzésveszély elmúltával kapták meg a betegek, így folyamatos rivaroxaban hatást biztosítva $(14,15)$.

Apixaban adásával is történt vizsgálat a K-vitamin-antagonistákkal összehasonlításban folyamatos adagolás tekintetében, amely során az apixabant a beavatkozás reggelén is megkapták a betegek, majd a hemosztázis biztosítása után a beavatkozás estéjén folytatták a gyógyszerszedést. A folyamatosan adagolt K-vitamin-antagonistákkal összevetésben nem találtak sem hatékonyságbeli, sem biztonságosságbeli különbséget (16).

Dabigatrannal kapcsolatban történt ezidáig egyedül randomizált, kontrollált, nagy esetszámú vizsgálat (RE-CIRCUIT) a témában, amely alapján a dabigatran folyamatos adagolása mellett is biztonsággal végezhető a pitvarfibrilláció abláció a K-vitamin-antagonistákkal összevetésben. A RE-CIRCUIT-vizsgálatban a major vérzéses szövődmények szignifikánsan kisebb arányban fordultak elő a dabigatrannal kezelt csoportban (17).

Mindezek alapján az új típusú antikoaguláns gyógyszerek használata a pitvarfibrilláció-abláció során periprocedurálisan egyre gyakoribb, és az eddigi vizsgálatok alapján biztonságosnak tủnik. A 2017 tavaszán megjelent HRS/EHRA/ECAS/APHRS/SOLAECE expert konszenzus dokumentum már a dabigatran és a rivaroxaban folyamatos periprocedurális adagolását javasolja (5). Az eddigi és jelenleg is folyó randomizált vizsgálatok eredményei alapján azonban várható, hogy a későbbiekben a pitvarfibrilláció-abláció elvégzése során az új típusú antikoaguláns szerek folyamatos adagolása lesz az általános. Ezt elősegíti, hogy a dabigatran esetében már rendelkezünk specifikus antidotummal (idarucizumab), és a rivaroxaban antidotuma is kifejlesztés alatt áll (andexant alfa) és a közeljövőben kereskedelmi forgalomban való megjelenése várható (18, 19). Ez a tény tovább növeli az ilyen típusú véralvadásgátló szerek periprocedurális alkalmazásának biztonságosságát.

A procedúra során jelentkező nem várt vérzéses szövődmény vagy perikardiális tamponád esetén a heparin hatás protaminnal felfüggesztendő, a beavatkozás leállítása, a vérzésforrás azonosítása, a vérzés ellátásának megkezdése javasolt. Ha a vérzés emellett gyorsan megáll, és ellátása sikeres, az alkalmazott tartós orális antikoaguláns szer hatásának felfüggesztése nem feltétlenül szükséges, mert a páciens így védve marad a tromboembóliás szövődményektől. Amenynyiben a vérzés a protamin adására és az alkalmazott primer vérzéscsillapító eljárások alkalmazására nem csillapodik, akkor a K-vitamin-antagonisták hatását friss fagyasztott plazma adásával, a dabigatran hatását annak specifikus antidótumával (idarucizumab), többi új típusú véralvadágátló szer hatását protrombin komplex koncentrátum vagy rekombináns VII. faktor adásával kell végezni (5).

\section{Transoesophagealis echokardiográfia a pit- varfibrilláció abláció előtt}

A pitvarfibriláció abláció előtt transoesophagealis echokardiográfiás (TEE) vizsgálattal lehet legbiztonságosabban kizárni az intrakardiális thrombus jelenlétét. Ezen vizsgálat rutinszerű elvégzése általános volt egészen a közelmúltig minden pitvarfibrilláció-ablációra váró páciens esetében a tervezett procedúra előtt 24 órán belül. Ennek oka, hogy a terápiás antikoaguláns kezelés mellett is előfordulhat intrakardiális (bal pitvari) thrombus, azonban ennek előfordulási valószínűsége a pitvarfibrilláció típusától, időtartamától, az aktuálisan fennálló szívritmustól, a bal pitvar méretétől és a páciens trombózisrizikójától függően változik. A 0 CHADS-VASc score mellett az intrakardiális thrombus előfordulási valószínüsége $<0,3 \%$, míg 2 vagy nagyobb CHADS-VASc score esetén $>5 \%$. Mindezek alapján a nagyon alacsony trombózisrizikójú, paroxizmálisan pitvarfibrilláló betegek esetében, akik a beavatkozás előtt aktuálisan sinusritmusban vannak, és megfelelő terápiás antikoaguláns kezelésben részesültek, a transoesophagealis echokardiográfiás vizsgálat nem feltétlenül szükséges, bár az elhagyásra vonatkozó konkrét ajánlás nincs. Nem hagyható el a TEE-vizsgálat magas trombózisrizikó (CHADS-VASc score $\geq 2$ ), illetve nem megfelelő terápiás antikoaguláns kezelés esetén (5).

Egy nagy esetszámú prospektív multicentrikus regiszter vizsgálat alapján rivaroxaban és apixaban adásával effektíven antikoagulált betegek esetében a transoesophgealis echokardigráfiás vizsgálat magas tromboembóliás rizikó (CHADS-VASc score $\geq 2$ ) mellett is biztonsággal elhagyható a pitvarfibriláció abláció előtt, bár ezen vizsgálatban a betegek nagy részénél 
intrakardiális echokardiográfia vezérelten történt a beavatkozás, amely minden esetben kizárta a bal pitvari thrombus jelenlétét (20).

Más képalkotó vizsgálat (CT/MRI) rutinszerü alkalmazása az intrakardiális thrombus kimutatása céljából nem javasolt. Intrakardiális echokardiográfia alternatívája lehet a TEE-nek, amennyiben a TEE nem elvégezhető valamilyen okból kifolyólag (5).

\section{Jobb pitvari (típusos) flatter-abláció}

A jobb pitvari flatter-ablációja során a pitvarfibrillációablációhoz képest alacsonyabb periprocedurális vérzési és tromboembóliás szövődményrátával kell számolni. Ennek oka, hogy a katétermanipuláció a jobb szívfélre, illetve a vénás keringésre lokalizálódik, nincs transzszeptális punkció. Mindezek okán a beavatkozás antikoagulált betegekben a K-vitamin-antagonista, illetve az új típusú antikoaguláns szer felfüggesztése nélkül elvégezhető. A nem, vagy nem kellő mértékben antikoagulált betegekben, perzisztáló ritmuszavar esetén TEE-vizsgálat szükséges az intrakardiális (bal pitvari fülcse) thrombus kizárása céljából. Postprocedurálisan pedig úgy kell a betegeket véralvadásgátló kezelésben részesíteni, mint a pitvarfibrilláció-áabláció után, mivel a jobb pitvari flatterrel jelentkező betegek nagy részében számolni kell a pitvarfibrilláció megjelenésével is (21).

\section{Bal pitvari fokális tachycardia, illetve bal oldali járulékos kötegek ablációja}

Ezen ritmuszavarok ablációja során a korábbi retrográd aortás megközelítés helyett mára már szintén a transzszeptalis katéterezés vált általánossá. Mégis, bár ezt részletesen nem vizsgálták, ezen beavatkozások tromboembóliás, illetve vérzési szövődményrátáját alacsonyabbnak tartjuk a pitvarfibrilláció-ablációhoz képest. Ennek oka a betegek fiatalabb kora, és kevesebb társbetegsége miatti alacsony tromboembóliás rizikó, a beavatkozás rövidebb volta, a kevesebb (egy) katéter használata a bal pitvarban, a rövidebb procedúra- és ablációs idő és a jóval kevesebb, illetve kisebb ablációs lézió. Mindezek miatt preprocedurálisan antikoaguláns kezelés nem szükséges. Az abláció alatt nem frakcionált heparin bolus, vagy folyamatos infúzió adagolásával az ACT 300 másodperc felett tartandó. Posztprocedurálisan antikoaguláns kezelés nem szükséges, és trombocitaaggregáció-gátló átmeneti adását sem támasztja alá evidencia, bár sok centrum követi azt a gyakorlatot, hogy az ilyen jellegű procedúrákat követően 3-4 hétig acetilszalicilsav monoterápiát ad (21). A jobb oldali járulékos pitvar-kamrai kötegek ablációja, lassú-pálya ablációk, jobb oldali fokális pitvari tachycardia-ablációk során a tromboemboliás rizikó alacsony, emiatt sem a beavatkozás előtt, sem az után alvadásgátló kezelés nem szükséges, beleértve a trombocitaaggregáció-gátló kezelést is, hacsak egyéb okból nem indokolt. A beavatkozás során azonban nem frakcionált heparin adása indokolt (21).

\section{Jobb kamrai tachycardia/extrasystolia- abláció}

A jobb kamrai tachycardia/extrasystolia-ablációk szövődményrátája alacsony (<1). A leggyakoribb szövődmény a perikardiális tamponád, amelynek oka a katétermanipuláció, illetve az abláció következtében kialakuló jobb kamra szabad falsérülés, amely gyakoribb mint a bal kamrai ablációk esetén. Ennek hátterében a bal kamra falánál jóval vékonyabb jobb kamrafal sérülékenysége áll. Tromboembóliás szövődmények szintén nagyon ritkán fordulnak elő. Ennél fogva a procedúrát megelőző antikoaguláns kezelés nem szükséges, ahogy posztprocedurális adásuk sem javasolt. A beavatkozások biztonsággal elvégezhetők az egyéb okból szedett véralvadásgátló kezelés megtartásával, ha az K-vitamin-antagonistával történik. Amennyiben a páciens új típusú antikoaguláns gyógyszert szed, akkor ezen szerek leállítása javasolt a gyógyszer farmakokinetikájától és a beteg vesefunkiójától függő időtartamra. Az antikoaguláns kezelés újraindítása javasolt a beavatkozás estéjén a komplett hemosztázis beálltával. Trombocitaaggregáció-gátló kezelés szintén nem indokolt postprocedurálisan. A beavatkozás során nem frakcionált heparin adása javasolt. Tervezett epikardiális beavatkozás előtt az egyéb okból szedett véralvadásgátló kezelés leállítása javasolt (21).

\section{Bal kamrai tachycardia/extrasystolia-abláció}

Bal kamrai tachycardia-abláció során a terápiás antikoagulálás elengedhetetlen. Az antikoagulálás mikéntje azonban alapvetően különbözik attól függően, hogy milyen úton „közelítik meg” a szubsztrátot (endokardiális: transzszeptalis, retrográd aortás, epikardiális). Endokardiális abláció során az artériás oldalra történő katéter bevezetéstől kezdve nem frakcionált heparinnal végzett antikoaguláció javasolt az ACT 300 sec felett tartásával. Amennyiben epikardiális ablációra kerül sor, a heparin csak az epikardiális tér szövődménymentes elérése után adandó. Ha endokardiális abláció során epikardiális ablációra kell áttérni, a heparin hatásának felfüggesztése javasolt protamin adásával. A procedúra előtt orális antikoguláns kezelés nem szükséges, amennyiben egyéb okból nem indokolt. A beavatkozást megelőzően transthoracalis echokardiográfia javasolt a bal kamrai thrombus kizárására strukturális szívbetegség (főként posztinfarktusos állapot, csökkent szisztolés balkamra-funkció) esetén. Az egyéb okból szedett orális antikoaguláns kezelés felfüggesztése endokardiális abláció esetén nem szükséges, amennyiben azt K-vitamin-antagonista adásával végzik. NOAC szedése esetén a véralvadásgátló kezelés felfüggesztése és LMWH-kezelésre történő átállás javasolt. Postprocedurálisan a véralvadásgátló kezelést a beavatkozást követő 4-6 óra elteltével újraindítható a komplett hemosztázis elérése után. Amennyiben orális antikoaguláns terápia 
egyéb okból nem szükséges, akkor ASA szedése javasolt 1-3 hónapig (21).

\section{Periprocedurális véralvadásgátló kezelés szívritmust szabályozó, illetve monitorozó eszkőz beültetése esetén}

Világszerte évente körülbelül 1250000 pacemaker és 410000 ICD (implantálható kardioverter defibrilátor) implantáció történik, és ez a szám folyamatosan emelkedik évről évre (22). A beavatkozásokon áteső betegek közel 50\%-a antitrombotikus (antikoaguláns vagy trombocitaaggregáció-gátló) kezelésben részesül (23). Az elmúlt évtizedekben a procedúrák komplexebbé válása mellett a beavatkozásra kerülő páciensek átlagéletkorának növekedésével a kardiális és nem kardiális komorbiditásaik számának emelkedése egyaránt hozzájárult a procedúrákkal járó szövődmények számának növekedéséhez. A PM/ICD/CRT-implantációk alapvetően minor sebészeti beavatkozásnak számítanak, és nem magas rizikójúak, de az antitrombotikus kezelés nagymértékben emeli a lehetséges (föként a vérzéses jellegű, illetve ezzel összefüggő) komplikációk arányát (26). A vérzéses szövődmény leggyakoribb formája a generátor zsebben kialakuló vérömleny, amely a páciensnek okozott kellemetlenségeken túl jelentős morbiditással és mortalitással járhat, mert növeli a hospitalizáció idejét, költségét, reoperációt tehet szükségessé (közel 50\%-ban), jelentősen emeli a késői infekciós szövődmények előfordulási valószínűségét $(25,29)$, és az antitrombotikus kezelés hosszabb idejű felfüggesztésének szükségessége miatt még emelkedett tromboembóliás kockázattal is jár. A primer implantációkhoz képest emelkedett vérzési rizikóval jár az elektródarevízió, elektródacsere, illetve a készülékek komplexebb rendszerré történő átalakítása (upgrade). A generátorcserék ugyan alacsonyabb vérzési rizikóval járnak, de ez sem elhanyagolható. Egyéb vérzéses szövődmények jóval ritkábban fordulnak elő (haemothorax, perikardiális tamponád, vaszkuláris komplikációk). Mindezek miatt körültekintő periprocedurális antitrombotikus kezelés szükséges az ilyen jellegű szövődmények elkerülésének minimalizálása érdekében $(23,24,25)$.

A procedúrák szövődményprofiljai alapján alacsony vérzési rizikójúnak tekintjük a loop-recorder implantációt és a készülék generátorcserét. Közepes vérzési rizikóval bír a primer PM/ICD/CRT-implantáció, a komplexebb rendszerré történő átalakítás (upgrade) és az elektródarevízió vagy -csere. Magas rizikójúnak tartjuk a percután elektróda-eltávolítást, illetve az amúgy közepes rizikójú beavatkozásokat is speciális körülmények fennállása esetén, mint ideiglenes pacemaker-kezelés, sürgősség, komplex anatómia (beleértve a veleszületett szívfejlődési rendellenességeket) reimplantáció elektróda extrakció után vagy infekciót követően (23) (1. táblázat).

\section{Periprocedurális antikoaguláns kezelés} K-vitamin-antagonista szedése mellett A korábban használatos protokoll, amely szerint a K-vitamin-antagonistával végzett tartós orális antikoaguláns kezelés a procedúra előtt felfüggesztendő, és könnyű molekulasúlyú vagy nem frakcionált heparin adásával végzett áthidaló kezelés szükséges a periprocedurális időszakban a tartós véralvadásgátló kezelés visszaállításáig, a beavatkozások nagy része tekintetében háttérbe szorulóban van, köszönhetően Birnie és munkatásai által végzett randomizált Bruise Control vizsgálatnak (27). Ennek alapján mára általánossá vált a gyakorlat, hogy a tartós véralvadásgátló kezelés felfüggesztése nélkül kell elvégezni a beavatkozásokat közepes, illetve magas tromboembóliás rizikó esetén $(4,21,23,28)$.

A megtartott antikoaguláns kezelés racionalitását az adja, hogy a mütét alatt ilyen esetben minden vérzésforrás jól látszik és emiatt a vérzéscsillapítás teljes lehet, és a mütétet követően nem történik véralvadásgátló kezelésbővítés. Míg ha a mütét az antikoaguláns kezelés leállitása mellett történik, akkor a mütét során rejtve maradhatnak olyan potenciális vérzésforrások, amelyek a mütét után, a terápiás antikoaguláns hatás elérésekor „aktiválódva” késői vérzéses szövődményt okoznak (23).

A tromboembóliás rizikó a mütétre kerülő antikoagulált betegek körében széles határok között mozog, és ez alapján merőben különbözik az ideális periprocedurális antikoaguláns kezelés mikéntje. Fokozott tromboembóliás rizikóval kell számolni a mübillentyüt viselő betegek, a pitvarfibrilláló betegek, a vénás tromboembóliás eseményt átélt betegek, a rosszindulatú daganattal élő és a trombofíliás betegek esetében.

Ezen belül magas tromboembóliás rizikóval kell számolni (10\%-nál nagyobb éves tromboemboliás kockázat) a mitralis mübillentyüt, több mübillentyüt, egylemezes vagy golyós aorta-mübillentyüt viselő betegek, a pitvarfibrilláló, magas ( $\geq 5)$ CHADS-VASc score-ral rendelkező, a közelmúltban stroke-on átesett, valvuláris eredetủ pitvarfibrillációban szenvedő, súlyos trombofí-

1. TÁBLÁZAT. A PM/ICD/CRT-műtétek vérzési rizikó szerinti osztályozása (23)

\begin{tabular}{|l|l|}
\hline Vérzési rizikó & Beavatkozás \\
\hline Alacsony & $\begin{array}{l}\text { Generátorcsere } \\
\text { ILR-implantáció }\end{array}$ \\
\hline Közepes & $\begin{array}{l}\text { PM/ICD/CRT-implantáció } \\
\text { Upgrade } \\
\text { Elektródacsere, illetve revízió }\end{array}$ \\
\hline Magas & $\begin{array}{l}\text { Elektróda-eltávolítás } \\
\text { Közepes rizikójú beavatkozás speciális } \\
\text { körülmények fennállása esetén, mint: } \\
\text { sürgösség, ideiglenes pacemaker-kezelés, } \\
\text { reimplantáció infekció után vagy } \\
\text { elektróda-extrakciót követően } \\
\text { Komplex anatómiai szituációk (GUCHD) }\end{array}$ \\
\hline
\end{tabular}


2. TÁBLÁZAT. Az orális antikoaguláns kezelés indikációját jelentő kórképek az éves tromboembóliás kockázat szerint csoportosítva (23)

\begin{tabular}{|c|c|c|c|}
\hline Trombózis rizikó & Múbillentyứ-viselés & Pitvafibrilláció & Vénás tromboembólia (VTE) \\
\hline Magas $>10 \%$ & $\begin{array}{l}\text { Mitralis mübillentyű } \\
\text { Több mübillentyü } \\
\text { Egylemezes vagy golyós } \\
\text { aorta-mübillentyű } \\
6 \text { hónapon belüli stroke/TIA }\end{array}$ & $\begin{array}{l}\text { CHADSVASc score } 5 \text { vagy } \\
\text { több } \\
3 \text { hónapon belüli stroke } \\
\text { Reumás billentyübetegség }\end{array}$ & $\begin{array}{l}3 \text { hónapon belüli VTE } \\
\text { Súlyos trombofília }\end{array}$ \\
\hline Közepes 5-10\% & $\begin{array}{l}\text { Kétlemezes aorta-mübillentyű ÉS } \\
\text { pitvarfirilláció, korábbi stroke, hipertónia, } \\
\text { diabétesz, } 75 \text { év feletti életkor }\end{array}$ & CHADSVASc 3-4 & $\begin{array}{l}\text { VTE 3-12 hónapon belül } \\
\text { Nem súlyos trombofília } \\
\text { Rekurrens VTE } \\
\text { Aktív rosszindulatú daganatos } \\
\text { megbetegedés }\end{array}$ \\
\hline Alacsony $<5 \%$ & $\begin{array}{l}\text { Kétlemezes aorta-mübillentyü } \\
\text { pitvarfibrilláció nélkül }\end{array}$ & $\begin{array}{l}\text { CHADSVASc 0-2 (stroke/TIA } \\
\text { nélkül!) }\end{array}$ & 12 hónapon túli VTE \\
\hline
\end{tabular}

liával élő, vagy a közelmúltban vénás tromboembóliás eseményt átélt betegek körében.

Közepes tromboembóliás kockázatúnak (éves tromboembóliás kockázat 5-10\% között) tekintendők a kétlemezes aorta-múbillentyűvel élő ÉS pitvarfibrilláló, vagy korábban stroke-on átesett, vagy magasvérnyomás-betegségben szenvedő, vagy diabéteszes vagy 75 évnél idősebb betegek, a pitvarfibrilláló, 3-4 CHADSVASc score-ral rendelkező, a 3-12 hónapon belül vénás tromboembóliás eseményt átélt, vagy nem súlyos trombofíliás, vagy aktív rosszindulatú daganattal élő, vagy ismétlődő vénás tromboembóliákat átélt betegek.

Alacsony tromboembóliás kockázatúak (éves rizikó $<5 \%$ ) a kétlemezes aorta-műbillentyűt viselő, de más rizikóval nem rendelkező, a pitvarfibrilláló, de alacsony (0-2) CHADS-VASc score-ral rendelkező (kivéve stroke/tranziens iszkémiás attak), vagy 12 hónapon túli vénás tromboembóliás eseményt átélt betegek (23) (2. táblázat).

A tervezett procedúra vérzési rizikója és a páciens tromboembóliás rizikója alapján kell meghatározni a periprocedurális antitrombotikus kezelési stratégiát. Ez alapján a lehetséges kombinációkat a 3. táblázat öszszegzi.

Összességében az alacsony tromboembóliás rizikó esetén az orális antikoaguláns kezelés a procedúra idejére leállítandó, és nem kell áthidaló kezelést alkalmazni. Bizonyos esetekben (amennyiben például a tromboembóliás rizikót korábbi stroke képezi) ilyenkor is elvégezhető a procedúra megtartott antikoaguláns kezelés mellett. A K-vitamin-antagonisták a hosszú felezési idejük miatt a procedúra előtt 3, illetve 5 nappal állítandók le acenocumarol, illetve warfarin esetén (23). Közepes, vagy magas tromboembóliás rizikó esetében az orális antikoaguláns kezelés megtartandó, a tervezett beavatkozást lehetőleg terápiás INR-szint mellett kell elvégezni.

A korábban általánosan használatos, könnyű molekulasúlyú vagy nem frakcionált heparinnal történő áthidaló kezeléssel kombinált antikoaguláns kezelésleállítás csak nagyon magas tromboembóliás rizikó és magas vérzési rizikó együttes fennállása esetén lehet alternatíva egyedi megfontolás alapján.

A K-vitamin-antagonisták újraindítása posztprocedurálisan a beavatkozás estéjén kezdődhet, így átlagosan a procedúrát követő 5 . napnál érhető el a terápiás INRszint warfarin esetében (23).

\section{Periprocedurális antikoaguláns kezelés új típusú antikoaguláns gyógyszerekkel}

Az új típusú antikoaguláns gyógyszerek tekintetében a PM/ICD/CRT-implantációk kapcsán egyelőre nem állnak rendelkezésre erős evidenciák a periprocedurális alkalmazást illetően. A perioperatív időszakban ezen gyógyszerek szedésének felfüggesztése általános, azonban ez a tromboembóliás rizikót háromszorosára emeli.

A folyamatos periprocedurális adagolásra vonatkozóan sem rendelkezünk megbízható adatokkal, a „Bruise Control" stratégia pedig nem alkalmazható az új típusú antikoaguláns gyógyszerek esetében. A jelenleg folyamatban lévő Bruise Control 2-vizsgálat (28) remélhetőleg választ ad az ezzel kapcsolatban felmerülő kérdésekre. Fentiek miatt ezen gyógyszerek leállítása javasolt a mütétek idejére az adott szer farmakokinetikája és a betegek vesefunkciós paraméterei alapján meghatározott időtartamra. Ezen új típusú szerek megfelelő időben leállítva nem emelik a procedúrák vérzési rizikóját a K-vitamin-antagonistákhoz viszonyítva (31) (4. táblázat).

Az új típusú véralvadásgátló szerek újraindítása a komplett hemosztázis elérését követően, de leghamarabb a beavatkozást követő 24 óra elteltével javasolt. Két kis esetszámú vizsgálat alapján a folyamatosan adagolt dabigatran mellett végzett PM/ICD/CRT-implantációk vérzéses szövődményrátája alacsony, és nem különbözik érdemben a folyamatos K-vitamin-antagonista hatásban végzett implantációkétól $(32,33)$.

\section{A trombocitaaggregáció-gátló kezelés periprocedurális alkalmazása}

Randomizált kontrollált vizsgálatok hiányában a trombocitaaggregáció-gátló (TAG) kezelés periprocedurális 
3. TÁBLÁZAT. A procedúra vérzési kockázata és a páciens tromboembóliás kockázata alapján javasolt periprocedurális antikoaguláns kezelési stratégiák (21)

\begin{tabular}{|l|l|l|l|l|}
\hline $\begin{array}{l}\text { Vérzési } \\
\text { rizikó }\end{array}$ & Alacsony $<\mathbf{5 \%}$ évente & $\begin{array}{c}\text { Közepes 5-10\% } \\
\text { évente }\end{array}$ & \multicolumn{1}{|c|}{ Magas $\mathbf{> 1 0 \%}$ évente } & $\begin{array}{c}\text { Nagyon magas. Mitralis } \\
\text { vagy több múbillentyú-vi- } \\
\text { selés és pitvarfibrilláció } \\
\text { vagy korábbi stroke }\end{array}$ \\
\hline Alacsony & $\begin{array}{l}\text { OAK-megtartás alacsony } \\
\text { INR }<2 \text { mellett -OAK- } \\
\text { felfüggesztés }\end{array}$ & $\begin{array}{l}\text { OAK-megtartás } \\
\text { alacsony } \\
\text { INR }<2 \text { mellett }\end{array}$ & $\begin{array}{l}\text { OAK-megtartás alacsony } \\
\text { terápiás INR-szint }<2,5 \text { mellett }\end{array}$ & $\begin{array}{l}\text { OAK-megtartás magas } \\
\text { terápiás INR }<3 \text { mellett }\end{array}$ \\
\hline Közepes & $\begin{array}{l}\text { OAK-megtartás alacsony } \\
\text { INR }<2 \text { mellett vagy } \\
\text { OAC-felfüggesztés }\end{array}$ & $\begin{array}{l}\text { OAK-megtartás ala- } \\
\text { Csony INR }<2 \text { mellett }\end{array}$ & $\begin{array}{l}\text { OAK-megtartás alacsony } \\
\text { terápiás INR-szint }<2,5 \text { mellett }\end{array}$ & $\begin{array}{l}\text { OAK-megtartás magas } \\
\text { terápiás INR }<3 \text { mellett }\end{array}$ \\
\hline Magas & OAK-leállítás & OAK-leállítás & $\begin{array}{l}\text { OAK-megtartás alacsony } \\
\text { terápiás INT <2,5 mellett } \\
\text { OAK-leállítás } \\
\text { Áthidaló kezelés megfontolható }\end{array}$ & $\begin{array}{l}\text { OAK-megtartás magas } \\
\text { terápiás INR }<3 \text { mellett } \\
\text { OAK-felfüggesztés, áthidaló } \\
\text { kezelés megfontolandó }\end{array}$ \\
\hline
\end{tabular}

alkalmazására vonatkozólag csak obszervációs vizsgálatokra, regiszterekre és más témájú randomizált vizsgálatok utólagos analízisére alapozott expert konszenzus evidenciákra támaszkodhatunk (5. táblázat). A trombocitaaggregáció-gátló (TAG - acetilszalicilsav, clopidogrel, ticlopidin, prasugrel) szerek szedése növeli a PM/ICD/CRT-implantációk vérzéses szövődményrátáját, és ezáltal a hosszú távú egyéb (föként infekciós) szövődmények arányát is. Az acetilszalicilsav monoterápia önmagában másfélszeresére, a kettős trombocitaaggregáció-gátlás közel ötszörösére emeli a vérzéses komplikációk arányát (26). A szekunder prevenciós TAG-monoterápia elhagyása önmagában háromszorosára emeli a tromboembóliás komplikációk arányát (34). Mindezek alapján a primer prevenciós céllal történő TAG-kezelés felfüggesztése javasolt a tervezett készülék-implantáció elött 5-7 nappal a vérzésveszély csökkentése céljából. A szekunder prevenciós céllal alkalmazott TAG-kezelés folytatandó, a gyógyszer leállítása nélkül javasolt a tervezett beavatkozás elvégzése $(21,23)$.

Kettős trombocitaaggregáció-gátló kezelés esetén a kezelés indikációjának újraértékelése mellett külön kell mérlegelni a tervezett beavatkozás vérzési rizikóját és a páciens tromboembóliás rizikóját az index esemény időpontja és a tervezett beavatkozás időpontja valamint a tromboembóliás rizikót adó klinikai szituáció (akut koronária szindróma, elektív perkután koronária-intervenció, hagyományos fémstentbeültetés, gyógyszerkibocsátó stentbeültetés, első-, második generációs gyógyszerkibocsátó stent) alapján.
Amennyiben lehetséges, az implantációt a kettős TAG-kezelés idejének letelte utáni időszakra kell halasztani. Ha nem lehetséges a procedúra halasztása, akkor alacsony tromboembóliás rizikó esetében az ASA-terápia megtartása és a $\mathrm{P}_{2} \mathrm{Y}_{12}$-gátló (clopidogrel, ticlopidin, prasugrel) elhagyása javasolt a beavatkozás elött 5 nappal.

Közepes, illetve magas tromboembóliás kockázat mellett a beavatkozást megszakítás nélküli kettős trombocitaaggregáció-gátló kezelés mellett kell elvégezni különös körültekintéssel.

Amennyiben a magas tromboembóliás rizikó mellett magas vérzési rizikó is fennáll, akkor a $\mathrm{P}_{2} \mathrm{Y}_{12}$-receptor-gátló kezelés felfüggesztése javasolt. Speciális esetekben, különös körültekintéssel rövid felezési idejű trombocitaaggregáció-gátló parenterális szerek adása (GPIIb/IIla-receptor-blokkoló, cangrelor) jöhet szóba áthidaló kezelésként csakis egyedi mérlegelés alapján. Ezen stratégia rutinszerủ alkalmazása nem javasolt (23).

\section{PM/ICD/CRT-implantáció antikoaguláns és antitrombocita kezelés együttes alkalmazása mellet}

Ha a szívritmus-szabályzó eszköz beültetésére olyan beteg esetében kell sort keríteni, aki egyszerre szed antikoaguláns és antitrombocita szereket, akkor minden esetben egyedi mérlegelés tárgyát kell képezze a periprocedurális antitrombotikus kezelés, mert erre vonatkozóan evidenciákkal nem rendelkezünk.

4. TÁBLÁZAT. Az új típusú antikoguláns gyógyszerek preprocedurális leállításának ideje a vesefunkciós paraméterek függvényében (18)

\begin{tabular}{|c|c|c|c|c|}
\hline Kreatinin clearance (ml/min) & Dabigatran & Apixaban & Rivaroxaban & Edoxaban \\
\hline$>\mathbf{8 0}$ & $\geq 24$ & $\geq 24$ & $\geq 24$ & $\geq 24$ \\
\hline $\mathbf{5 0 - 8 0}$ & $\geq 36$ & $\geq 24$ & $\geq 24$ & NA \\
\hline $\mathbf{3 0 - 5 0}$ & $\geq 48$ & $\geq 24$ & $\geq 24$ & NA \\
\hline $\mathbf{1 5 - 3 0}$ & Nem indikált & $\geq 36$ & $\geq 36$ & NA \\
\hline
\end{tabular}


5. TÁBLÁZAT. Trombocitaaggregáció-gátló kezelési stratégiák kettős TAG-kezelés mellett PM/ICD/CRT-implantációk során (ACS - akut koronária szindróma, BMS - hagyományos fémstent, DES - gyógyszerkibocsátó stent)

\begin{tabular}{|c|c|c|c|}
\hline \multirow[t]{2}{*}{ Vérzési rizikó } & \multicolumn{3}{|l|}{ Tromboembóliás rizikó } \\
\hline & $\begin{array}{l}\text { Alacsony: } \\
\text { ACS } \geq 12 \text { hónap } \\
\text { BMS } \geq 1 \text { hónap } \\
\text { DES } \geq 12 \text { hónap }\end{array}$ & $\begin{array}{l}\text { Közepes: } \\
\text { ACS 6-12 hónap } \\
\text { DES 6-12 hónap }\end{array}$ & $\begin{array}{l}\text { Magas: } \\
\text { ACS }<6 \text { hónap } \\
\text { BMS }<1 \text { hónap } \\
\text { DES }<6 \text { hónap }\end{array}$ \\
\hline Alacsony & $\begin{array}{l}\text { ASA-folytatás } \\
\text { P2Y }_{12} \text {-receptor-gátló leállítás }\end{array}$ & $\begin{array}{l}\text { ASA-folytatás P2Y }{ }_{12} \text {-recep- } \\
\text { tor-gátló folytatás }\end{array}$ & $\begin{array}{l}\text { ASA-folytatás } \mathrm{P}_{2} \mathrm{Y}_{12^{-}} \\
\text {receptor-gátló folytatás }\end{array}$ \\
\hline Közepes & $\begin{array}{l}\text { ASA-folytatás } \\
\text { P2Y }_{12} \text {-receptor-gátló leállítás }\end{array}$ & $\begin{array}{l}\text { ASA-folytatás } \mathrm{P}_{2} \mathrm{Y}_{12} \mathrm{R} \text {-gátló } \\
\text { leállítás, majd újraindítás telítő } \\
\text { adaggal } 24-48 \text { óra múltán }\end{array}$ & $\begin{array}{l}\text { ASA-folytatás P2Y }{ }_{12} \text {-receptor-gátló foly- } \\
\text { tatás Áthidaló kezelés (GPIIb/IIla- } \\
\text { receptor-blokkoló, cangrelor)? }\end{array}$ \\
\hline Magas & $\begin{array}{l}\text { ASA-leállítás P2Y } \text { 12-recep- }_{\text {tor-gátló leállítás }} \\
\text { tor }\end{array}$ & $\begin{array}{l}\text { Procedúrahalasztás, ha lehet, ha } \\
\text { nem: ASA-folytatás } \\
\text { P2Y }_{12} \text {-receptor-gátló leállítás }\end{array}$ & $\begin{array}{l}\text { Procedúrahalasztás, ha lehet, ha nem: } \\
\text { ASA-folytatás P2Y } \\
\text { receptor-gátló leállítás Áthidaló kezelés } \\
\text { (GPIlb/Illa-receptor-blokkoló, cangrelor)? }\end{array}$ \\
\hline
\end{tabular}

Külön értékelni kell az antikoaguláns és az antitrombocita kezelés indikációját és az elmaradásukból származó esetleges trombotikus szövődményeket és a beavatkozás vérzési szövődményprofilját. Ezek alapján kell döntést hozni arra vonatkozólag, hogy melyik kezelést állítsuk le, illetve tartsuk meg a periprocedurális időszakban.

Ha kettős trombocitaaggregáció-gátló kezelés indikciója is fennáll az orális antikoguláns kezelés mellett, akkor a beavatkozás halasztása javasolt a kettős TAG-kezelés kötelező időtartamán túlra, amennyiben lehetséges $(21,23)$.

\section{Következtetések}

Az elektrofiziológiai beavatkozások száma folyamatosan emelkedik, miközben a beavatkozásra kerülő betegek egyre idősebbek, egyre több társbetegséggel rendelkeznek és egyre többen közülük különböző típusú antitrombotikus kezelésben részesülnek. Az új típusú antikoagulánsok megjelenésével a véralvadásgátló kezelési lehetőségek elmúlt években történt kibővülése nagyban megkönnyítette a betegek hatékony és biztonságos kezelését, de jelentősen bonyolította a periprocedurális antitrombotikus kezelési stratégiákat az invazív elektrofiziológiai beavatkozások során. Az ezen témában végzett vizsgálatok eredményei alapján mára már evidencia, hogy amikor csak lehet, a véralvadásgátló kezelés megszakítása nélkül végezzük a beavatkozásokat, így biztosítva a legalacsonyabb tromboembóliás és vérzéses kockázatot a beavatkozásra kerülő betegeknek. Mindemellett azonban a szövődmények minimalizálása érdekben minden esetben egyénileg mérlegelni kell a beavatkozásra kerülő páciens tromboembóliás rizikóját (CHADS-VASc score), vérzési rizikóját (HAS-BLED score), a procedúra vérzési rizikóját és az alkalmazott antitrombotikus kezelés aktuális indikációját.
Irodalom

1. Elena Arbelo, et al. Contemporary management of patients undergoing atrial fibrillation ablation: inhospital and 1-year follow-up findings from the ESC-EHRA atrial fibrillation ablation long-term registry. European Heart Journal 2017; 0: 1-14. CLINICAL RESEARCH DOI 10.1093/eurheartj/ehw564

2. Mond HG, Proclemer A. The $11^{\text {th }}$ world survey of cardiac pacing and implantable cardioverter-defibrillators: calendar year 2009 aWorld Society of Arrhythmia's project. Pacing Clin Electrophysiol 2011; 34: 1013-27. DOI: 10.1111/j.1540-8159.2011.03150.x.

3. Kirchhof P, et al. 2016 ESC Guidelines for the management of atrial fibrillation developed in collaboration with EACTS: The Task Force for the management of atrial fibrillation of the European Society of Cardiology (ESC) Developed with the special contribution of the European Heart Rhythm Association (EHRA) of the ESC Endorsed by the European Stroke Organisation (ESO). Eur Heart J https://doi. org/10.1093/eurheartj/ehw210

4. Michele Brignole, et al. 2013 ESC Guidelines on cardiac pacing and cardiac resynchronization therapy. European Heart Journal 2013; 34: 2281-2329. DOI 10.1093/eurheartj/eht150

5. Calkins H, et al. 2017 HRS/EHRA/ECAS/APHRS/SOLAECE EXpert Consensus Statement on Catheter and Surgical Ablation of Atrial Fibrillation. Heart Rhythm 2017. DOI:10.1016/j.hrthm.2017.05.012. 6. Christine I, et at. Incidence of Bleeding-Related Complications During Primary Implantation and Replacement of Cardiac Implantable Electronic Devices. J Am Heart Assoc 2017; 6: e004263. DOI: 10.1161/JAHA.116.004263.

7. Eunice Yang, et al. Factors impacting complication rates for catheter ablation of atrial fibrillation from 2003 to 2015. Europace 2017; 19: 241-249. Dol 10.1093/europace/euw178

8. Di Biase L, et al. Periprocedural Stroke and Bleeding Complications in Patients Undergoing Catheter Ablation of Atrial Fibrillation With Different Anticoagulation Management: Results From the Role of Coumadin in Preventing Thromboembolism in Atrial Fibrillation (AF) Patients Undergoing Catheter Ablation (COMPARE) Randomized Trial. Circulation 2014; 129: 2638-2644. DOI: 10.1161/CIRCU LATIONAHA.113.006426

9. Connolly SJ, Ezekowitz MD, Yusuf S, et al. RE-LY Steering Committee and Investigators. Dabigatran versus warfarin in patients with atrial fibrillation. N Engl J Med 2009; 361: 1139-51. DOI: 10.1056 NEJMoa0905561.

10. Patel MR, Mahaffey KW, Garg J, et al. ROCKET AF Investigators. Rivaroxaban versus warfarin in nonvalvular atrial fibrillation. $\mathrm{N}$ Engl J Med 2011; 365: 883-91. 18 DOI: 10.1056/NEJMoa1009638. 11. Granger CB, Alexander JH, McMurray JJ, et al. ARISTOTLE Committees and Investigators. Apixaban versus warfarin in patients with atrial fibrillation. N Engl J Med 2011; 365: 981-92. DOI:10.1056 NEJMoa1107039. 
12. Stepanyan G, et al. Safety of new oral anticoagulants for patients undergoing atrial fibrillation ablation. J Interv Card Electrophysiol 2014; 40: 33-38. DOI: 10.1007/s10840-014-9888-9.

13. Providencia R, et al. Rivaroxaban and dabigatran in patients undergoing catheter ablation of atrial fibrillation. Europace 2014; 16 : 1137-1144. DOI10.1093/europace/euu007

14. Lakkireddy $\mathrm{D}$, et al. Feasibility and safety of uninterrupted rivaroxaban for periprocedural anticoagulation in patients undergoing radiofrequency ablation for atrial fibrillation: results from a multicenter prospective registry. J Am Coll Cardiol 2014; 63: 982-988. http:/l dx.doi.org/10.1016/j.jacc.2013.11.039

15. Cappato R, et al. VENTURE-AF Investigators. Uninterrupted rivaroxaban vs. uninterrupted vitamin $\mathrm{K}$ antagonists for catheter ablation in non-valvular atrial fibrillation. Eur Heart J 2015; 36:18051811. DOI 10.1093/eurheartj/ehv177

16. Biase L, et al. Feasibility and safety of uninterrupted periprocedural apixaban administration in patients undergoing radiofrequency catheter ablation for atrial fibrillation: Results from a multicenter study. Heart Rhythm 2015; 12: 1162-1168. DOI: http://dx.doi. org/10.1016/j.hrthm.2015.02.028

17. Hugh Calkins, et al. for the RE-CIRCUIT Investigators* Uninterrupted Dabigatran versus Warfarin for Ablation in Atrial Fibrillation. N Engl J Med 2017 Apr 27; 376(17): 1627-1636. DOI: 10.1056/NEJMoa1701005. Epub 2017 Mar 19.

18. Pollack CV, Jr, et al. Idarucizumab for Dabigatran Reversal. N Engl J Med 2015; 373(6): 511-20. 845. DOl:10.1016/j.annemerg med.2016.11.025

19. Siegal DM, et al. Andexanet Alfa for the Reversal of Factor Xa Inhibitor Activity. N Engl J Med 2015; 373(25): 2413-24. DOI:10.158 6/17474086.2016.1135046

20. Di Biase L, et al. Is transesophageal echocardiogram mandatory in patients undergoing ablation of atrial fibrillation with uninterrupted novel oral anticoagulants? Results from a prospective multicenter registry. Heart Rhythm 13(6): 1197-1202. DOI: 10.1016/j. hrthm.2016.03.024.

21. Christian Sticherling, et al. Antithrombotic management in patients undergoing electrophysiological procedures: a European Heart Rhythm Association (EHRA) position document endorsed by the ESCWorking Group Thrombosis, Heart Rhythm Society (HRS), and Asia Pacific Heart Rhythm Society (APHRS). Europace 2015; 17: 1197-1214. DOI:10.1093/europace/euv190

22. Mond HG, Proclemer A. The 11th world survey of cardiac pacing and implantable cardioverter-defibrillators: calendar year 2009 - a World Society of Arrhythmia's project. Pacing Clin Electrophysiol 2011; 34: 1013-27. DOI: 10.1111/j.1540-8159.2011.03150.x

23. Zacà $V$, et al. Managementof antithrombotic therapy in patients undergoing electrophysiological device surgery. Europace 2015 Jun;
17(6): 840-54. DOI: 10.1093/europace/eun357 Epub 2015 Feb 24

24. Uslan DZ, et al. Cardiovascular implantable electronic device replacement infections and prevention: results from the REPLACE registry. Pacing Clin Electrophysiol 2012; 35: 81-7. DOI: $10.1111 /$ j.1540-8159.2011.03257.

25. Christine I, et al. Incidence of Bleeding-Related Complications During Primary Implantation and Replacement of Cardiac Implantable Electronic Devices. J Am Heart Assoc 2017; 6: e004263. DOI: 10.1161/JAHA.116.004263.

26. Bernard ML, et al. Meta-analysis of bleeding complications associated with cardiac rhythm device implantation. Circ Arrhythm Electrophysiol 2012 Jun 1; 5(3): 468-74. DOI: 10.1161/CIR CEP.111.969105. Epub 2012 Apr 24.

27. Birnie DH, et al. Pacemaker or defibrillator surgery without interruption of anticoagulation. N Engl J Med 2013; 368: 2084-93. DOl: 10.1056/NEJMoa1302946.

28. Sant'anna RT, et al. Meta-nalysis of continuous oral anticoagulants versus heparin bridging in patients undergoing CIED surgery: reappraisal after the BRUISE study. Pacing Clin Electrophysiol 2015 Apr; 38(4): 417-23. DOI: 10.1111/pace.12557 Epub 2014 Dec 26

29. Essebag V, et al. BRUISE CONTROL Investigators. Clinically Significant Pocket Hematoma Increases Long-Term Risk of Device Infection: BRUISECONTROL INFECTION Study. J Am Coll Cardiol 2016 Mar 22; 67(11): 1300-8. DOI:10.1016/j.jacc.2016.01.009.

30. Essebag Vidal, et al. Strategy of Continued Versus Interrupted Novel Oral Anticoagulant at Time of Device Surgery in Patients with Moderate to High Risk of Arterial Thromboembolic Events: The BRUISE CONTROL-2 Trial. American Heart Journal (2015), DOI: 10.1016/j.ahj.2015.12.007

31. Healey JS, et al. RE-LY Investigators. Periprocedural bleeding and thromboembolic events with dabigatran compared with warfarin: results from the Randomized Evaluation of Long-Term Anticoagulation Therapy (RE-LY) randomized trial. Circulation 2012 Jul 17; 126(3): 343-8. DOI: 10.1161/CIRCULATIONAHA.111.090464. Epub 2012 Jun

32. Rowley CP, et al. Safety of continuous anticoagulation with dabigatran during implantation of cardiac rhythm devices. Am J Cardiol 2013; 111: 1165-8. DOI: 10.1016/j.amjcard.2012.12.046.

33. Jennings JM, et al. Cardiovascular implantable electronic device implantation with uninterrupted dabigatran: comparison to uninterrupted warfarin. J Cardiovasc Electrophysiol 2013; 24: 1125-9. DOI: $10.1111 /$ jce.12214.

34. Biondi-Zoccai GG, et al. A systematic review and meta-analysis on the hazards of iscontinuing or not adhering to aspirin among 50,279 patients at risk for coronary artery disease. Eur Heart J 2006; 27: 2667-74. DOI10.1093/eurheartj/ehl334 